\title{
Mediatization of Islam in the Digital Era: Opportunity or Threat?
}

\author{
Sukarman $^{1}$, Fatah Syukur ${ }^{2}$, Raharjo $^{3}$ \\ \{pakar@unisnu.ac.id ${ }^{1}$, fsyukur68@ @mail.com ${ }^{2}$, raharjo@walisongo.ac.id ${ }^{3}$ \} \\ Universitas Islam Nahdlatul Ulama Jepara ${ }^{1}$, UIN Walisongo Semarang ${ }^{2}$, UIN \\ Walisongo Semarang ${ }^{3}$,
}

\begin{abstract}
The religious activities of Muslims have experienced a shift in the digital era 4.0. The tremendous development of information technology has changed the religious pattern of Muslims around the world. This paper aims to answer how the form of a religious shift in the Muslim community, to what extent the development of information technology has implications for the religious pattern of Muslims. The approach used in this qualitative descriptive study is a phenomenological approach. The research data was extracted through documentation from several kinds of literature, both books, and scientific journal articles. The data is then analyzed to obtain answers to the research questions. The result of this research is that ibadah activities and muamalah activities have been affected by advances in information technology so that they experience a shift in religious patterns from manual to online-based. The conclusion of this paper is that technological progress has not only contributed greatly to the religious pattern of Muslims but has also become a threat to Muslims.
\end{abstract}

Keywords: Islam, media, digital era.

\section{Introduction}

The era of the industrial revolution 4.0 has had a significant impact on the lives of the world community. This new era is also known as the digital revolution, marked by a widespread internet, cellular with more sophisticated and cheaper sensors. Artificial intelligence and machine learning are other indicators of this era. Digital technologies which consist of computer hardware, software, and networks are not essentially new, but after the 
interruption of the third industrial revolution, they have become more sophisticated and integrated. As a result, this digital revolution has transformed society and the global economy. In other words, the Internet has changed the lifestyle of the world community. ${ }^{1}$ Renald Kasali called this change the great shifting. The implication is cyber-based community activities. Among them are cyber education, cyber economy, cyber romance, cybercrime, and cyber religion. ${ }^{2}$ One of the implications of the digital revolution era is the religious aspect. So that this digital revolution also has implications for religious activities. The digital era is marked by the development of information technology that has a broad impact on aspects of the life of the Muslim community. The religious activity of Muslims cannot be separated from the internet. Shirley in her research entitled "Muslim surfers on the internet: using the theory of planned behavior to examine the factors influencing engagement in online religious activities" states that the internet influences the Muslim community. religiosity is positively related to involvement in religious activities online. ${ }^{3}$ The research confirms that digital media has a big role in religious activities regardless of age. Another form of religious activity as expressed by Echchaibi in "Muslimah Media Watch: Media activism and Muslim choreographies of social change" state that digital media is a tool for Muslim women activists to influence the process of social change through blogs. One of the popular blogs is Muslimah Media Watch. A group of Muslim women establishes a discussion forum and shares information about gender and current issues through blogs. Blogs are also used by Muslim youth as a discursive and performative space. Through blogs, young Muslims compete and debate about modernity and so on. ${ }^{4}$ Eckert \&

\footnotetext{
${ }^{1}$ Klaus Schwab, The Fourth Industrial Revolution (New York, USA: CURRENCY, 2017).

${ }^{2}$ Rheinald Kasali, The Great Shifting, Series of Disruption (Jakarta: Gramedia, 2018).

${ }^{3}$ Shirley S. Ho, Waipeng Lee, and Shahiraa Sahul Hameed, "Muslim Surfers on the Internet: Using the Theory of Planned Behaviour to Examine the Factors Influencing Engagement in Online Religious Activities," New Media \& Society 10, no. 1 (2014), doi: $10.1177 / 1461444807085323$.

4 Nabil Echchaibi, "Muslimah Media Watch: Media Activism and Muslim Choreographies of Social Change," Journalism 14, no. 7 (2013), doi:10.1177/1464884913478360.
} 
Chadha in their research entitled "Muslim bloggers in Germany: an emerging counterpublic" states that digital media in the form of blogs are also used by Muslim minorities in Germany as a space to challenge public discourse to challenge dominant public discourses through various discursive practices. ${ }^{5}$ Evolvi in "Hybrid Muslim identities in digital space: The Italian blog Yalla" states that Muslim youth in Italy also use blogs as a means to fortify themselves and maintain their existence. This is done because so far Islam is considered incompatible with European values ."6

Herbert in "Theorizing religion and media in contemporary societies: An account of religious' publicization" "states that the combination of advances in information technology and media developments that occur in society Placing digital media significantly directs the tendency of public presence. Religious discourse and symbols are forms of religious publications. The public presence of religion is increasing through digital media. “... And tending to increase the public presence or distribution of religious symbols and discourses, a process described as religious' publicization '. These processes have implications for religious authority. "7

Based on the literature and previous studies, it is said that there has been massive mediation of religion. In other words, digital media has changed the religious pattern of the world's Muslim community. The problem is what is the implication of religious mediation on Islam and Muslims. Become an opportunity for the existence of Islam or vice versa.

\section{Result and Discussion}

The era of the industrial revolution and digital media has completely changed the religious pattern of the world's Muslim community by offering the

5 Stine Eckert and Kalyani Chadha, "Muslim Bloggers in Germany: An Emerging Counterpublic," Media, Culture \& Society 35, no. 8 (2013), doi:10.1177/0163443713501930.

${ }^{6}$ Giulia Evolvi, "Hybrid Muslim Identities in Digital Space: The Italian Blog Yalla," 2017, doi:10.1177/0037768617697911.

7 David E J Herbert, "Theorizing Religion and Media in Contemporary Societies : An Account of Religious 'Publicization ," European Journal of Cultural Studies 14, no. 6 (2011), doi:10.1177/1367549411419981. 
convenience, practicality, efficiency, and effectiveness it offers. Various religious patterns that have experienced a paradigm shift as a result of digital media are as follows.

\subsection{Dakwah / Tabligh}

In the early days of its existence, Islam was spread through tabligh or da'wah activities using conventional media, namely word of mouth and face to face physically in one assembly. As was done by the Messenger of Allah (saw) to his relatives and close friends secretly and openly to the wider community. Although this conventional media of da'wah is successful, its access is limited and requires a long duration. ${ }^{8}$ With the development of the era of preaching or tabligh activities have developed from time to time. Era 4.0 which is synonymous with the digital era has a major impact on tabligh media. Tabligh is not only done traditionally using conventional media. Da'wah media develop following technological developments.

This sophisticated technological development is a great opportunity for cadres and preachers to continue to think about ways of preaching. There is nothing but ijtihad in looking for opportunities. Da'wah messages that can be channeled to various media. As has been seen by business activists by continuing to innovate their products to various media that can reach a wide range of consumers. ${ }^{9}$ Before online media developed as it is today, one of the most popular media as a media for preaching was television. Television is one of the most popular media for preaching and is easily accessible by almost all groups and levels of society. Television can grab people's attention so that this media was and is still a popular da'wah medium.

Television is used as a da'wah because it has several advantages, namely: first, the advantages and characteristics of television, especially in terms of its closeness to everyday life. Television is a unique cultural product.

${ }^{8}$ Haidar Putra Daulay, Pendidikan Islam Dalam Lintasan Sejarah, 1st ed. (Jakarta: Kencana, 2013).

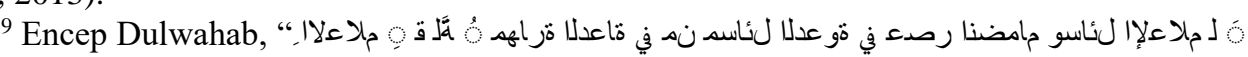

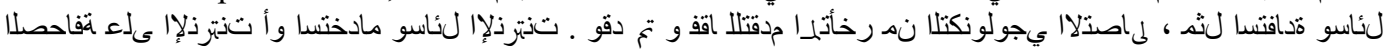

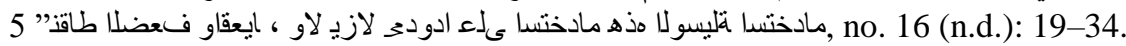


The forms of news, talk, visualization, and dramatization developed by television give birth to a public culture that is completely different from what it was before. Second, as an audio-visual (listen to view) medium, the advantage of television lies in its very high persuasive power, because the audience can see both live images and sound. Even the sound and live images can be received by the audience at a tabligh or sermon event that is happening, through live coverage. Third, television has a very wide reach (coverage) in disseminating messages quickly with all its impacts on the lives of individuals and society. ${ }^{10}$

In the digital era, people tend to search by accessing referrals online. In fact, it can be said that online media has become the prima donna of preaching media for the community. This is because of the convenience it offers. To acquire religious knowledge, people do not need to go far to find information about religion. The public can reduce the duration of time compared to traveling a certain distance to visit majlis ta'lim or simply visiting certain ulama to obtain religious information. People only need to provide electronic devices such as laptops, devices, smartphones or smartphones, and internet access. ${ }^{11}$

Some examples of virtual preachers are Felix Siauw and Hanan Attaki. Even though Felix Siauw and Hanan Attaki both preached through social media by using short posts or videos, in some parts Felix Siauw was more dominant in discussing social and political issues in contrast to Hanan Attaki who was more dominant in discussing the health of goodness or about the love between men and women. ${ }^{12}$

\subsection{Prayer}

Prayer is compulsory to worship for Muslims with certain conditions. Muslims need insight and information about many things related to prayer. In

\footnotetext{
${ }^{10}$ Ahmad Zaini, "Dakwah Melalui Televisi," Jurnal AT-TABSYIR 3, no. 1 (2015): 1-20.

${ }^{11}$ Fadly Usman, "Efektivitas Penggunaan Media Online Sebagai Sarana Dakwah" 1, no. 1 (2016): 1-8.

12 Nor Latifah and Romario Romario, "Trendsetter Muballigh Di Medsos: Analisis Framing Instagram Felix Siauw Dan Hanan Attaki," Jurnal Studi Agama Dan Masyarakat 15, no. 1 (2019): 36-48, doi:10.23971/jsam.v15i1.1150.
} 
general, the Islamic community obtains insights, knowledge, and information manually from the explanations of religious leaders, scholars, kyai. To understand and obtain information about Islam, Muslims get information about the history of famous tourist attractions in the Islamic world, or the tombs of famous Islamic kings. ${ }^{13}$ virtual learning patterns. To understand thaharoh Fiqh (purification), tayammum, najis, prayer requirements, pillars of prayer, things that cancel prayer, how to remove hadas and najis, wudhu an android-based fiqh application was created. ${ }^{14}$ The problem that arises, in this case, is scientific nature. In Islam, scientific sanad must be continued up to the Prophet Muhammad. When learning through online media, the identity of the teacher is unclear. The identity of the teacher is not even known. When people encounter this kind of phenomenon, there will be doubts and the validity of their knowledge.

In the digital era, there is a shift from manual learning patterns to The next aspect related to prayer is the determination of prayer times. In the digital era 4.0, the majority of people, has many activities in scope that are not only local and even global, as is the case with the Muslim community. The implication is that they have high mobility and explore various places, countries, and other destinations around the world. As a Muslim who must pray. Prayer services in the digital era of the Muslim community no longer need to mess around with prayer times. For example, being in another nonMuslim based country were to mark prayer times, of course, there is no call to prayer. The Mobile web helps to determine prayer times for the digital era. So that anyone and anywhere can access prayer times easily. ${ }^{15}$

13 Nurdin Abd Halim, "PENGGUNAAN MEDIA INTERNET DI KALANGAN REMAJA,” Jurnal RISALAH 26, no. 3 (2015): 132-50.

${ }^{14}$ Meti Zuhairotul Atiroh, Bunyamin, and Eri Satria, "RANCANG BANGUN APLIKASI FIQIH IBADAH SHALAT BERBASIS ANDROID," Jurnal Algoritma Sekolah Tinggi Teknologi Garut III. 11, no. 1 (2014): 1-9.

15 Sri Tita Faulina and Sri Tita Faulina, "SISTEM INFORMASI PENJADWALAN PETUGAS SHOLAT 5 WAKTU DAN JUM' AT PADA MASJID JAMI' HUJJATUL ISLAM BERBASIS WEB MOBILE Program Studi Manajemen Informatika, AMIK AKMI Baturaja J1 . A . Yani No . 267 A Baturaja, OKU, Sumatera Selatan," JUSIM 1, no. 1 (2016): 53-62. 
Another aspect that is also related to prayer is the determination of the direction of the qibla. To find out the direction of the qibla, there are already many android applications and there is even a robot technology that functions to determine the direction of the qibla. ${ }^{16}$ even when Muslims are in a nonMuslim majority country, the community has difficulty finding a mosque. For matters of prayer, Muslims no longer need to worry about this. To find out prayer times, qibla direction, recommendations for the nearest mosque are available through an Android-based smartphone connected to Google. ${ }^{17}$

\subsection{Zakat}

Zakat in the digital era is becoming more modern technology, starting from the institution, raising it to the distribution process. Zakat management has shifted from manual to online-based. The Muslim community in the digital era wants everything to be easy, including in matters of zakat. The busyness and activities of today's Muslim community demand convenience and practicality. They do not have to bother having to find the poor or asnaf themselves to distribute their zakat. Online-based zakat management makes it easier for Muslims in matters of zakat. ${ }^{18}$ Problems related to online zakat, among others; 1) organizers who are not necessarily trustworthy may raise doubts for muzak. 2) the distribution of zakat is ideally distributed to the poor around the muzak, but when zakat is online, the distribution can be anywhere depending on the manager. This means that the elements of its users are not felt by the people around Muzakki.

\section{4 al-Qur'an}

${ }^{16}$ Luqman Hakim et al., "PROTOTYPE ROBOT UNTUK MENENTUKAN ARAH KIBLAT DENGAN TANDA SHAF SHOLAT," in Prosiding Elektronik (E-Proceeding) PIMNAS Program Kreatifitas Mahasiiswa Karsa-Cipta (PKM-KC) (Jakarta: Direktorat Penelitian dan Pengabdian Kepada Masyarakat DITJEN DIKTI KEMENDIKBUD RI, 2014), 1-8.

17 Yuda Putra Utama, Elfi Tasrif, and Yeka Hendriyani, "PERANCANGAN DAN PENGEMBANGAN APLIKASI JAM PENGINGAT WAKTU SHOLAT ARAH KIBLAT DAN REKOEMNDASI MASJID TERDEKAT," Jurnal Vokasional Teknik Elektronika \& Informatika Vol. 4, no. 1 (2016): 72-81.

${ }^{18}$ Nurul Nadiah Ahmad et al., "The Application of Unified Theory of Acceptance and Use of Technology ( UTAUT ) for Predicting the Usage of E-Zakat Online System" 3, no. 4 (2014): 63-67. 
Al-Qur'an in the digital era experienced a metamorphosis. People usually read the Qur'an using the traditional printed version of the paperback format called the Mushaf. Initially, the Qur'an was in the form of a conventional Mushaf which was presented in printed form using paper. However, with advances in information technology, the Koran changed its form to a digital al-Qur'an. ${ }^{19}$ The recent advent of smart technologies such as smartphones, digital devices, and tablets has brought the routine of daily life under one touch and Muslims are adopting these new tools with exponential growth. ${ }^{20}$ This digital Al-Qur'an is shown to be accessible through several media such as smartphones and tablets. Alwi in his research entitled "Digital Quran Applications on Smart Phones and Tablets: A Study of the Foundation Program Students" stated that students' interest in reading the Koran is at a good level. However, $32.6 \%$ to $53.0 \%$ of them are not really sure about the rules involved when using digital Quran apps stored on the device. ${ }^{21}$ The problem that arises is that the Mushaf is increasingly being abandoned because people have switched to digital Al-Qur'an. The implication is that the sacredness of the Al-Qur'an is reduced because the digital Alquran is questionable.

Khotmil Qur'an, as a ritual commonly practiced by Muslims, has shifted. Initially, the ritual of reading the Quran by memorizing the al-Qur'an (khotmil Qur'an) was carried out by attending and gathering in one assembly together. Activities that were originally carried out by meeting physically in the real world can then be carried out without having to attend and meet physically but in cyberspace and conditioned through social media such as WhatsApp. ${ }^{22}$ Koran khotmil activities are coordinated and conditioned

\footnotetext{
${ }^{19}$ Mohammed Zakariah et al., "Digital Quran Computing : Review , Classification , and Trend Analysis," 2017, doi:10.1007/s13369-017-2415-4.

${ }^{20}$ Muhammad Khurram Khan and Yasser M. Alginahi, "The Holy Quran Digitization: Challenges and Concerns," Life Science Journal 10, no. 2 (2013): 156-64.

${ }^{21}$ Engku Ahmad Zaki Engku Alwi et al., "Digital Quran Applications on Smart Phones and Tablets: A Study of the Foundation Programme Students," Asian Social Science 10, no. 15 (2017): 212-16, doi:10.5539/ass.v10n15p212.

22 Ariza Rusni and Elysa Evawani Lubis, "PENGGUNAAN MEDIA ONLINE WHATSAPP DALAM AKTIVITAS KOMUNITAS ONE DAY ONE JUZ (ODOJ) DALAM
} 
through social media, starting from the distribution of readings (maqro ') and determining time limits and notifications for those who have read the parts. Jam'iyah khotmil Qur'an in social media generally takes the form of One Day One Juz (ODOJ), One Week One Juz (OWOJ), and so on. ${ }^{23}$

On the one hand, digital media makes religious activities easier, more practical, and more efficient. Digital media can increase the spread of Islam. But on the other hand, digital media is an easy and cheap means of spreading heretical teachings, dangerous ideologies, and radicalism.

1. Radicalisme and terorisme

Terrorism is not a question of who the perpetrators, groups, and networks are. However, more than that, terrorism is an act that has roots in beliefs, doctrines, and ideologies that can attack people's consciousness. The growth of terrorism depends on the land where it grows and develops. If it lives in an arid land, then terrorism is difficult to find a place, on the contrary, if it lives infertile land, it will quickly develop. According to experts, this fertile field is a society polluted by extreme fundamentalism or religious radicalism.

Radicalism is the embryo of the birth of terrorism. Radicalism is an attitude that longs for total change and is revolutionary by overturning existing values drastically through violence and extreme actions. Several characteristics can be recognized from radical attitudes and understanding. 1) intolerant (don't want to respect other people's opinions \& beliefs), 2) fanatical (always feel right about yourself; think others are wrong), 3) exclusive (differentiate themselves from Muslims in general) and 4) revolutionary (tend to use other methods). violence to achieve goals).

Having a radical attitude and understanding alone does not have to make someone fall into the understanding and act of terrorism. Other factors

MENINGKATKAN MINAT TILAWAH ODOJER DI KOTA PEKANBARU," JOM FISIP 2, no. 1 (2017): 1-15.

${ }^{23}$ Eva F Nisa, "Social Media and the Birth of an Islamic Social Movement: ODOJ ( One Day One Juz ) in Contemporary Indonesia Social Media and the Birth of an Islamic Social Movement: ODOJ ( One Day One Juz ) in Contemporary Indonesia," Indonesia and the Malay World 46, no. 134 (2018): 24-43. 
motivate someone to join a terrorist network. This motivation is caused by several factors. First, domestic factors, namely domestic conditions such as poverty, injustice, or feeling disappointed with the government. Second, international factors, namely the influence of the foreign environment that provides the impetus for the growth of religious sentiments such as global injustice, arrogant foreign policy, and modern imperialism of superpowers. Third, cultural factors that are closely related to shallow religious understanding and narrow and lexical interpretations of scriptures. Radical attitudes and understandings and motivated by the various factors above often make someone choose to join terrorist acts and networks.

It cannot be denied that the media and the internet have influenced the spread of radicalism in Indonesia. Although basically, the spread of radicalism in Indonesia takes many ways, such as cadre organizations, mosque speeches managed by radical groups, publishing magazines and books as well as through various webs on the internet. ${ }^{24}$ The internet has become an effective medium in spreading the ideology of understanding both under religious rules and norms as well as those that are deviant. One of them is the modern anti-hadith movement which rejects the use of hadith as a second source to broadcast its vision via the internet. ${ }^{25}$ A concrete example of the propaganda of radical teachings carried by the Dabiq magazine was published online. The propaganda carries the mission of jihad by exploiting certain verses to fuel the spirit of jihad and lead to anarchist actions.

"Since the establishment of the Islamic State, Da'esh has been extremely successful in producing English-language propaganda for the purposes of recruiting extremists and radicalizing the disenfranchised. This study utilizes Spier's 500,000+ word corpus of Da'esh extremist periodicals and specifically examines the extent to which particular verses from Qur'anic scripture are utilized in the first 14 issues of Dabiq, which were published during a period of 22

${ }^{24}$ Abdul Munip, "Menangkal Radikalisme Agama Di Sekolah," Jurnal Pendidikan Islam I, no. 2 (2012): 159-81, doi:10.14421/jpi.2012.12.159-181.

${ }^{25}$ AHMAD SANUSI AZMI, MOHD YUSUF ISMAIL, and ZULHILMI MOHAMED NOR, "GERAKAN ANTI HADITH MODEN: KAJIAN TERHADAP PENYEBARAN PEMIKIRAN MELALUI INTERNET,” Jurnal Penvelidikan Islam, 2011. 
months (July 2014 to April 2016). Almost three-quarters of the 624 quoted or referenced verses are cited only once or twice, and approximately $70 \%$ of these are unique. The six most frequently attested verses come from five books of the Qur'an (Al-Ma'idah, AlAnfal, Al-Hashr, At-Tawbah and Al-Imran) and account for $8.17 \%$ of all the cited scripture. This study considers the translations and content of each verse and the manner in which they are included in the periodicals as reflective of their significance." 26

In fact, the use of internet media for radical propaganda is not only used by radical Islamic groups but also by radical groups from other religious communities. In the digital era, these groups make use of cellular telephone communication technology, computing, and the internet to carry out their activities.

"Hindu nationalist organizations, Islamic radicals and Christian fundamentalists rank among the most creative, effective users of network technologies - telecommunications, computing, mobile telephony and the internet." 27

The spread of radical understanding through the media and the internet is very dangerous because this radical understanding is a seed that can grow and develop into a threat of terrorism. This movement has the characteristics of fanatical, exclusive, and revolutionary intolerance. In other words, this group does not want to respect the opinions and beliefs of others, achieve goals by using violent means, differentiate themselves from other Muslims, and feel the most self-righteous. It is undeniable that the mass media have contributed greatly to the propaganda and effectively spread of radicalism and terrorism. How could I not, the fact is that almost everyone is inseparable from the media and the internet so that radical propaganda will

${ }^{26}$ Troy E Spier, "Extremist Propaganda and Qur' Anic Scripture : A ' Radical ' CorpusBased Study of the Dabiq," Discourse \& Society 29, no. 5 (2018): 1-15, doi:10.1177/0957926518770265.

${ }^{27}$ Evert S Tangkudung, Meicsy E I Najoan, and Dringhuzen J Mamahit, “Aplikasi Tata Cara Ibadah Berbasis Android," E-Journal Teknik Informatika 14, no. 1 (2018): 1-7. 
easily spread and reach its intended target. ${ }^{28}$ According to BNPT, there are 208 radical sites. Among them; https // www.suara-islam.com, https // www.voa-islam.com, https // www.portal-Islam.id, https // www.eramuslim.com, https // www.arrahmah.com, https // www, hidayatullah.com, https // www.kiblat.net https // www.suara-islam.com, and so on. These accounts often make posts containing slander against the kyai, ulama, NU, and Pancasila. ${ }^{29}$

2. Cyber education.

Teachers in Islamic education are the central figures of education. Islamic education departs and stands from the revelations brought by the messengers (Prophets and apostles) which were then continued by the scholars as heirs of the Prophets. Ulama in the context of Islamic education is defined as people who are knowledgeable and spread knowledge (educators). Then educators are more broadly translated into various names and terms that are more specific according to their scope. Educators in Islam are known as mu'allim, murobbi, muaddib. Nata said that there are at least 13 terms commonly used in Islamic education, namely; tarbiyah, ta'lim, ta'dib, tahdzib, mauodzah, Riyadloh, Tazkiyah, talqin, tadris, tafaqquh, tabyin, tazkirah, irsyad. ${ }^{30}$ All of these terms are also specific to the designation of educators.

The digital era is marked by advances in information technology. Making a tremendous shift in all fields including education. The existence of the internet makes educators and students pampered with abundant information. The internet provides any kind of information including religious content. That is, to seek and find answers to problems, people will look for answers to easy and fast sources, namely the internet, rather than asking ulama figures. The internet has largely shifted the role of ulama and teachers in education. This phenomenon certainly has advantages and disadvantages. The advantage is that people will easily get information about religious matters

${ }^{28}$ Leni Winarni, “Media Massa Dan Isu Radikalisme Islam,” Jurnal Komunikasi Massa 7, no. 2 (2014).

${ }^{29}$ Moh Yasir Alimi, Mediatisasi Agama Post-Truth Dan Ketahanan Nasional., 1st ed. (Yogyakarta: LKiS, 2018).

${ }^{30}$ Abuddin Nata, Ilmu Pendidikan Islam, 2nd ed. (Jakarta: Kencana, 2012). 
easily, quickly, instantly, and efficiently compared to visiting ulama to study or ask for enlightenment. So it automatically raises the phenomenon of cyber education and cyber teachers.

Cyber education may no longer be something foreign in this era, especially in the era of the Covid-19 pandemic, learning is carried out online or in distance learning. ${ }^{31}$ This is done to break the chain of the spread of the Coronavirus. ${ }^{32}$ This model of distance education may still be considered good from the dimensions of Islamic education because a teacher and student interactions still occur with the help of the media. Learning activities occur through the transfer of knowledge and the transfer of value between students and teachers. So that the validity of the source of knowledge comes from a trusted sanad. The validity of science will be guaranteed because the ulama are the successors of the messages of the Prophets and apostles. Even today many scholars have adapted from conventional learning to cyber-based forms of learning. Major ulema scholars and large Islamic boarding schools have now adapted to the digital era by creating recitation forums through various social

${ }^{31}$ Albitar Septian Syarifudin, "Impelementasi Pembelajaran Daring Untuk Meningkatkan Mutu Pendidikan Sebagai Dampak Diterapkannya Social Distancing," Jurnal Pendidikan Bahasa Dan Sastra Indonesia Metalingua 5, no. 1 (2020): 31-34, doi:10.21107/metalingua.v5i1.7072; Nurul Lailatul Khusniyah and Lukman Hakim, "Efektivitas Pembelajaran Berbasis Daring: Sebuah Bukti Pada Pembelajaran Bahasa Inggris," Jurnal Tatsqif 17, no. 1 (2019): 19-33, doi:10.20414/jtq.v17i1.667; Sukarman, "SINERGITAS PERAN TRI PUSAT PENDIDIKAN DALAM PEMBELAJARAN BERBASIS DARING DI MASA PANDEMI COVID-19," Magistra 11, no. 2 (2020): 112-29.

32 Nur Rohim Yunus and Annissa Rezki, "Kebijakan Pemberlakuan Lockdown Sebagai Antisipasi Penyebaran Corona Virus Covid-19," SALAM; Jurnal Sosial \& Budaya Syar-I 7, no. 3 (2020): 227-38, doi:10.15408/sjsbs.v7i3.15083; Ade Chita Putri Harahap, Dinda Permatasari Harahap, and Samsul Rivai Harahap, "Analisis Tingkat Stres Akademik Pada Mahasiswa Selama Pembelajaran Jarak Jauh Dimasa Covid-19," Biblio Couns: Jurnal Kajian Konseling Dan Pendidikan 3, no. 1 (2020); Nika Cahyati and Rita Kusumah, "Peran Orang Tua Dalam Menerapkan Pembelajaran Di Rumah Saat Pandemi Covid 19," Jurnal Golden Age 4, no. 1 (2020): 152-59; Dalinama Telaumbanua, "Urgensi Pembentukan Aturan Terkait Pencegahan Covid-19 Di Indonesia," QALAMUNA: Jurnal Pendidikan, Sosial, Dan Agama 12, no. 1 (2020): 59-70, doi:10.37680/qalamuna.v12i01.290; Sukarman, "SINERGITAS PERAN TRI PUSAT PENDIDIKAN DALAM PEMBELAJARAN BERBASIS DARING DI MASA PANDEMI COVID-19"; Indra Rahmatullah, "Jaminan Hak Kesehatan Pekerja Work From Office Selama Masa PSBB Covid-19,” Jurnal Buletin Hukum Dan Keadilan 4, no. 1 (2020): 57-62. 
media platforms. At least some young Nahdlatul Ulama figures preach on social media. As reported by coil.com. ${ }^{33}$

1. Kalis Mardiasih

This NU female figure preaches in online media raising issues of women and gender justice in the view of Islam. His works and writings. His writings are often published by many online media.

\section{Nadirsyah Hosen}

A young NU figure who preaches on social media is Nadirsyah Hosen. NU activists who are also lecturers at Monash University use social media as a medium of da'wah. His da'wah activities were carried out by answering netizens' questions about issues related to religion. Nadirsyah Hosen uses Twitter by uploading tweets containing da'wah. It displays easy-to-understand language in every upload. Sometimes he also gives a touch of humor. He also displays a book of figh in the form of screenshots in explaining things to his followers on Twitter

\section{Akhmad Sahal}

Similar to Nadirsyah Hosen, Akhmad Sahal is the administrator of the American Nahdlatul Ulama (PCINU) Special Branch. He often replies to his followers' mentions on social media. Issues surrounding the teachings of Islam became the main topic in his discussions with netizens. For example, the issue of the case of dogs entering the mosque.

\section{Irwan Masduqi}

Gus Irwan, his nickname, uses da'wah media on social media. He often writes down his ideas and thoughts on Facebook status. He likes to do live streaming when there are recitations or religious activities at his pesantren.

\section{Savic Ali}

Muhammad Ayafiq Alielha or Savic Ali is one of the young NU activists working in the media industry. Savic is the director of $\mathrm{Nu}$ Online

33 "Https://kumparan.com/berita-heboh/5-Figure-Muda-Nu-Yang-Aktif-Berdakwah-DiMedia-Social-1rQdR8uEhky/full.,” 2021. 
and a founder of Islami. co. savic displays da'wah content on the two Islamic media.

An alarming phenomenon in cyber education in the digital era is learning without a teacher. Because the internet is considered to have provided all information and knowledge, it is no longer important whether there is a teacher or not. Because information is easily obtained without a teacher. This is certainly a serious problem when religious affairs are not clear from the source of knowledge and it is not clear who the teacher is. This can lead to misguidance and wrong understanding because learning religion without a teacher then the teacher is the devil. The true teachings will be continued until the Prophet Muhammad SAW. otherwise, the disconnection of the scientific chain will be doubted.

Cyber education on the one hand has a positive impact on education, 1) abundant sources of information 2) ease of access 3) independence in learning. But on the other hand, especially religious education is a serious problem. 1) invalid learning resources, 2) no teacher guidance, 3) the potential to lead to wrong/heretical teachings.

\section{Conclusion}

Based on the above data, Islamic mediation, besides having a positive impact, also has a negative impact. Digital media is not only an effective means for the spread of Islam, but digital media is also an effective means for radical Islamic groups in spreading their understanding and ideology. Islamic mediation in the digital era has two sides like a double-edged knife. One side of Islamic mediation has the potential to spread Islam. For example, the phenomenon of online da'wah through social media, which implies that people can easily obtain the religious information they need. Another implication is the emergence of virtual scholars, virtual preachers, virtual preachers. Regardless of qualified scientific or otherwise. There is also a virtual preacher who is popular and qualified in his knowledge. On the other hand, the danger is that some preachers are not qualified in science but are popular. Another 
danger is the provocative preachers through his lectures on social media which not only disturbs the public. Digital media is a potential vehicle for the spread of radical Islamic ideology and has the potential to develop the seeds of terrorism. This can damage the image of Islam as a religion of grace. The impact is that Islam is imaged as a terrorist religion so that the phenomenon of Islamophobia appears in the global community. This study concludes that the mediatization of Islam can be an opportunity for the benefit of the people. But it also becomes a threat and becomes a ticking time bomb that could explode and destroy Muslims themselves. However, Islam must still exist in any space and time. Because when Islam is not responsive and adaptive to media developments, Islam will sink. Therefore, Muslims must use the media as a place for worship and da'wah to spread the Islamic mission of rahmatan lil alamin. 


\section{Bibliography}

Ahmad, Nurul Nadiah, Mahlindayu Tarmidi, Izzatul Ussna Ridzwan, Masdiah Abdul Hamid, and Rusli Abdul Roni. "The Application of Unified Theory of Acceptance and Use of Technology ( UTAUT ) for Predicting the Usage of E-Zakat Online System” 3, no. 4 (2014): 63-67.

Alimi, Moh Yasir. Mediatisasi Agama Post-Truth Dan Ketahanan Nasional. 1st ed. Yogyakarta: LKiS, 2018.

Alwi, Engku Ahmad Zaki Engku, Norazmi Anas, Mohd. Syahril Ibrahim, Ahmad Fadhir Mat Dahan, and Zuriani Yaacob. "Digital Quran Applications on Smart Phones and Tablets: A Study of the Foundation Programme Students." Asian Social Science 10, no. 15 (2017): 212-16. doi:10.5539/ass.v10n15p212.

Atiroh, Meti Zuhairotul, Bunyamin, and Eri Satria. "RANCANG BANGUN APLIKASI FIQIH IBADAH SHALAT BERBASIS ANDROID.” Jurnal Algoritma Sekolah Tinggi Teknologi Garut III. 11, no. 1 (2014): 1-9.

AZMI, AHMAD SANUSI, MOHD YUSUF ISMAIL, and ZULHILMI MOHAMED NOR. "GERAKAN ANTI HADITH MODEN: KAJIAN TERHADAP PENYEBARAN PEMIKIRAN MELALUI INTERNET." Jurnal Penvelidikan Islam, 2011.

Cahyati, Nika, and Rita Kusumah. "Peran Orang Tua Dalam Menerapkan Pembelajaran Di Rumah Saat Pandemi Covid 19." Jurnal Golden Age 4, no. 1 (2020): 152-59.

Daulay, Haidar Putra. Pendidikan Islam Dalam Lintasan Sejarah. 1st ed. Jakarta: Kencana, 2013.

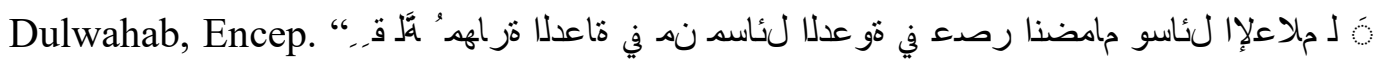

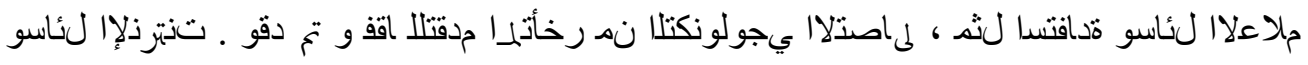

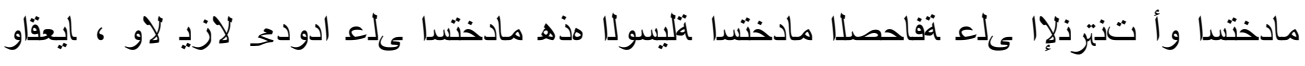
5 ف. فعضلا طاقن, no. 16 (n.d.): 19-34.

Echchaibi, Nabil. "Muslimah Media Watch: Media Activism and Muslim Choreographies of Social Change." Journalism 14, no. 7 (2013). doi:10.1177/1464884913478360. 
Eckert, Stine, and Kalyani Chadha. "Muslim Bloggers in Germany: An Emerging Counterpublic." Media, Culture \& Society 35, no. 8 (2013). doi:10.1177/0163443713501930.

Evolvi, Giulia. "Hybrid Muslim Identities in Digital Space: The Italian Blog Yalla," 2017. doi:10.1177/0037768617697911.

Faulina, Sri Tita, and Sri Tita Faulina. "SISTEM INFORMASI PENJADWALAN PETUGAS SHOLAT 5 WAKTU DAN JUM'AT PADA MASJID JAMI' HUJJATUL ISLAM BERBASIS WEB MOBILE Program Studi Manajemen Informatika, AMIK AKMI Baturaja J1 . A . Yani No . 267 A Baturaja, OKU , Sumatera Selatan.” JUSIM 1, no. 1 (2016): 53-62.

Hakim, Luqman, Rifqi Budi Raharjo, Didik Dwi Waluyo, Politeknik Elektronika, and Negeri Surabaya. "PROTOTYPE ROBOT UNTUK MENENTUKAN ARAH KIBLAT DENGAN TANDA SHAF SHOLAT." In Prosiding Elektronik (E-Proceeding) PIMNAS Program Kreatifitas Mahasiiswa KarsaCipta (PKM-KC), 1-8. Jakarta: Direktorat Penelitian dan Pengabdian Kepada Masyarakat DITJEN DIKTI KEMENDIKBUD RI, 2014.

Halim, Nurdin Abd. "PENGGUNAAN MEDIA INTERNET DI KALANGAN REMAJA.” Jurnal RISALAH 26, no. 3 (2015): 132-50.

Harahap, Ade Chita Putri, Dinda Permatasari Harahap, and Samsul Rivai Harahap. "Analisis Tingkat Stres Akademik Pada Mahasiswa Selama Pembelajaran Jarak Jauh Dimasa Covid-19.” Biblio Couns: Jurnal Kajian Konseling Dan Pendidikan 3, no. 1 (2020).

Herbert, David E J. "Theorizing Religion and Media in Contemporary Societies : An Account of Religious ' Publicization .'” European Journal of Cultural Studies 14, no. 6 (2011). doi:10.1177/1367549411419981.

Ho, Shirley S., Waipeng Lee, and Shahiraa Sahul Hameed. "Muslim Surfers on the Internet: Using the Theory of Planned Behaviour to Examine the Factors Influencing Engagement in Online Religious Activities." New Media \& Society 10, no. 1 (2014). doi:10.1177/1461444807085323.

"Https://kumparan.com/berita-heboh/5-Figure-Muda-Nu-Yang-Aktif-BerdakwahDi-Media-Social-1rQdR8uEhky/full.," 2021. 
Kasali, Rheinald. The Great Shifting, Series of Disruption. Jakarta: Gramedia, 2018.

Khan, Muhammad Khurram, and Yasser M. Alginahi. "The Holy Quran Digitization: Challenges and Concerns." Life Science Journal 10, no. 2 (2013): 156-64.

Khusniyah, Nurul Lailatul, and Lukman Hakim. "Efektivitas Pembelajaran Berbasis Daring: Sebuah Bukti Pada Pembelajaran Bahasa Inggris.” Jurnal Tatsqif 17, no. 1 (2019): 19-33. doi:10.20414/jtq.v17i1.667.

Latifah, Nor, and Romario Romario. "Trendsetter Muballigh Di Medsos: Analisis Framing Instagram Felix Siauw Dan Hanan Attaki.” Jurnal Studi Agama Dan Masyarakat 15, no. 1 (2019): 36-48. doi:10.23971/jsam.v15i1.1150.

Munip, Abdul. "Menangkal Radikalisme Agama Di Sekolah.” Jurnal Pendidikan Islam I, no. 2 (2012): 159-81. doi:10.14421/jpi.2012.12.159-181.

Nata, Abuddin. Ilmu Pendidikan Islam. 2nd ed. Jakarta: Kencana, 2012.

Nisa, Eva F. "Social Media and the Birth of an Islamic Social Movement: ODOJ ( One Day One Juz ) in Contemporary Indonesia Social Media and the Birth of an Islamic Social Movement: ODOJ ( One Day One Juz ) in Contemporary Indonesia." Indonesia and the Malay World 46, no. 134 (2018): 24-43.

Rahmatullah, Indra. "Jaminan Hak Kesehatan Pekerja Work From Office Selama Masa PSBB Covid-19.” Jurnal Buletin Hukum Dan Keadilan 4, no. 1 (2020): $57-62$.

Rusni, Ariza, and Elysa Evawani Lubis. "PENGGUNAAN MEDIA ONLINE WHATSAPP DALAM AKTIVITAS KOMUNITAS ONE DAY ONE JUZ (ODOJ) DALAM MENINGKATKAN MINAT TILAWAH ODOJER DI KOTA PEKANBARU.” JOM FISIP 2, no. 1 (2017): 1-15.

Schwab, Klaus. The Fourth Industrial Revolution. New York, USA: CURRENCY, 2017.

Spier, Troy E. 'Extremist Propaganda and Qur' Anic Scripture : A ' Radical' Corpus-Based Study of the Dabiq.” Discourse \& Society 29, no. 5 (2018): 115. doi:10.1177/0957926518770265. 
Sukarman. "SINERGITAS PERAN TRI PUSAT PENDIDIKAN DALAM PEMBELAJARAN BERBASIS DARING DI MASA PANDEMI COVID19." Magistra 11, no. 2 (2020): 112-29.

Syarifudin, Albitar Septian. "Impelementasi Pembelajaran Daring Untuk Meningkatkan Mutu Pendidikan Sebagai Dampak Diterapkannya Social Distancing." Jurnal Pendidikan Bahasa Dan Sastra Indonesia Metalingua 5, no. 1 (2020): 31-34. doi:10.21107/metalingua.v5i1.7072.

Tangkudung, Evert S, Meicsy E I Najoan, and Dringhuzen J Mamahit. “Aplikasi Tata Cara Ibadah Berbasis Android.” E-Journal Teknik Informatika 14, no. 1 (2018): 1-7.

Telaumbanua, Dalinama. "Urgensi Pembentukan Aturan Terkait Pencegahan Covid-19 Di Indonesia." QALAMUNA: Jurnal Pendidikan, Sosial, Dan Agama 12, no. 1 (2020): 59-70. doi:10.37680/qalamuna.v12i01.290.

Usman, Fadly. "Efektivitas Penggunaan Media Online Sebagai Sarana Dakwah" 1, no. 1 (2016): $1-8$.

Utama, Yuda Putra, Elfi Tasrif, and Yeka Hendriyani. "PERANCANGAN DAN PENGEMBANGAN APLIKASI JAM PENGINGAT WAKTU SHOLAT ARAH KIBLAT DAN REKOEMNDASI MASJID TERDEKAT.” Jurnal Vokasional Teknik Elektronika \& Informatika Vol. 4, no. 1 (2016): 72-81.

Winarni, Leni. "Media Massa Dan Isu Radikalisme Islam.” Jurnal Komunikasi Massa 7, no. 2 (2014).

Yunus, Nur Rohim, and Annissa Rezki. "Kebijakan Pemberlakuan Lockdown Sebagai Antisipasi Penyebaran Corona Virus Covid-19.” SALAM; Jurnal Sosial \& Budaya Syar-I 7, no. 3 (2020): 227-38. doi:10.15408/sjsbs.v7i3.15083.

Zaini, Ahmad. "Dakwah Melalui Televisi." Jurnal AT-TABSYIR 3, no. 1 (2015): $1-20$.

Zakariah, Mohammed, Muhammad Khurram, Khan Omar, and Khaled Salah. "Digital Quran Computing: Review , Classification , and Trend Analysis," 2017. doi:10.1007/s13369-017-2415-4. 